\title{
Discovery and significance of Naraoia from the Qiandongian (lower Cambrian) Balang Formation, Eastern Guizhou, South China
}

\author{
JIN PENG, YUANLONG ZHAO \& HAIJING SUN
}

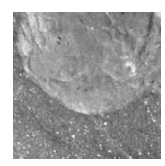

\begin{abstract}
Naraoia is a taxon represented by commonly non-mineralized fossil found in lower-middle Cambrian strata and widely distributed in China, North America, and is an important component of Burgess Shale-type biotas. Well-preserved representatives of Naraoia are known from the Chengjiang and Kaili biotas of South China. Here, we report a new species of Naraoia, Naraoia taijiangensis sp. nov. from the Balang Fauna, Guizhou, South China. The new species clearly represents an intermediate morphology between Misszhouia longicadata and $N$. cf. N. compacta. It is obvious that there is a body-morphologic evolution for Naraoia from the Cambrian Series 2 to Cambrian Series 3 (lower Cambrian to the middle Cambrian). N. taijiangensis sp. nov. provides new data about evolution and geographical range of this genus. $\bullet$ Key words: Naraoia, Balang Formation, Qiandongian (lower Cambrian), Geyi, Taijiang, China.
\end{abstract}

PENG, J., ZHAO, Y.L. \& SUN, H.J. 2012. Discovery and significance of Naraoia from the Qiandongian (lower Cambrian) Balang Formation, Eastern Guizhou, South China. Bulletin of Geosciences 87(1), 143-150 (5 figures). Czech Geological Survey, Prague. ISSN 1214-1119. Manuscript received September 12, 2010; accepted in revised form March 23, 2011; published online February 10, 2012; issued February 29, 2012.

Jin Peng, Yuanlong Zhao \& Haijing Sun, College of Resource and Environment Engineering, Guizhou University, Guiyang, Guizhou, 550003, China; gzpengjin@ sina.com• Jin Peng, State Key Laboratory Palaeobiology and Stratigraphy (NIGP.CAS), Nanjing, Jiangsu 210008, China

Naraoia is a taxon represented by commonly nonmineralized fossil found in lower-middle Cambrian strata and widely distributed in China, North America (Walcott 1912, Zhang \& Hou 1985, Zhao et al. 1999, Steiner et al. 2005). The dorsal sclerotised area of representatives of $\mathrm{Na}$ raoia is subdivided two distinct parts, a cephalic shield and a posterior shield. The genus ranges from Cambrian Series 2 to late Silurian in age (Walcott 1912, Zhang \& Hou 1985, Lin 2006, Zhang et al. 2007, Caron et al. 2004). Based on material from the middle Cambrian (Series 3) Burgess Shale of Canada, North America, Walcott (1912) described the type species of Naraoia, Naraoia compacta and specially erected the family Naraoiidae as different from common trilobites. Walcott (1931) described a second species of Naoroia, N. spinifer from Burgess Shale. Simonetta \& Delle Cave (1975) described other two additional species N. pammon and N. halia from the Burgess Shale. Whittington (1977) restudied specimens of Walcott's collections and new specimens in detail, and concluded that two species, N. pammon and N. halia described by Simonetta \& Delle Cave, are invalid, and recognized Naraoia as an unusual trilobite lacked thoracic segment. Robison (1984) reported Naraoia compacta from the lower Cambrian Gibson Jack Formation of Idaho and the middle Cambrian
Marjum Formation of House Range, Utah, North America and approved the synonyms of Whittington. Zhang \& Hou (1985) reported two species of Naraoia, N. longicaudata Zhang \& Hou, 1985 and N. spinosa Zhang \& Hou, 1985 from the lower Cambrian Chengjiang Biota of Yunnan, China. N. longicaudata was transferred to newly erected taxon, Misszhouia longicaudata by Chen et al. (1997). Sequentially, $N$. sp. from the Cambrian Emu Bay Shale, Kangaroo Island, South Australia (Nedin 1999), N. cf. N. compacta, N. sp. from the middle Cambrian Kaili Biota of Guizhou, China (Zhao et al. 1999), and N. cf. N. longicaudata and $N$. spinosa from the early Cambrian Niutitang Biota of Guizhou, China (Steiner et al. 2005) were reported. Then, the new study indicates that $N$. sp. from Emu Bay Shale is undiagnosis (Patterson et al. 2010). Due to its widespread occurrence in various Lagerstätten, Naraoia is an important soft-bodied component of Burgess Shale-type biotas. Fossils of Naraoia from three biotas of Chengjiang, Kaili, and the Burgess Shale are well-preserved, with alimentary diverticulae in the cephalic area and the alimentary canal in the axial area readily observed by the naked eye (Zhang \& Hou 1985, Briggs et al. 1994, Hou et al. 1999, Zhao et al. 2005, Lin 2006). Caron et al. (2004) described $N$. bertiensis from the upper Silurian the Bertie 


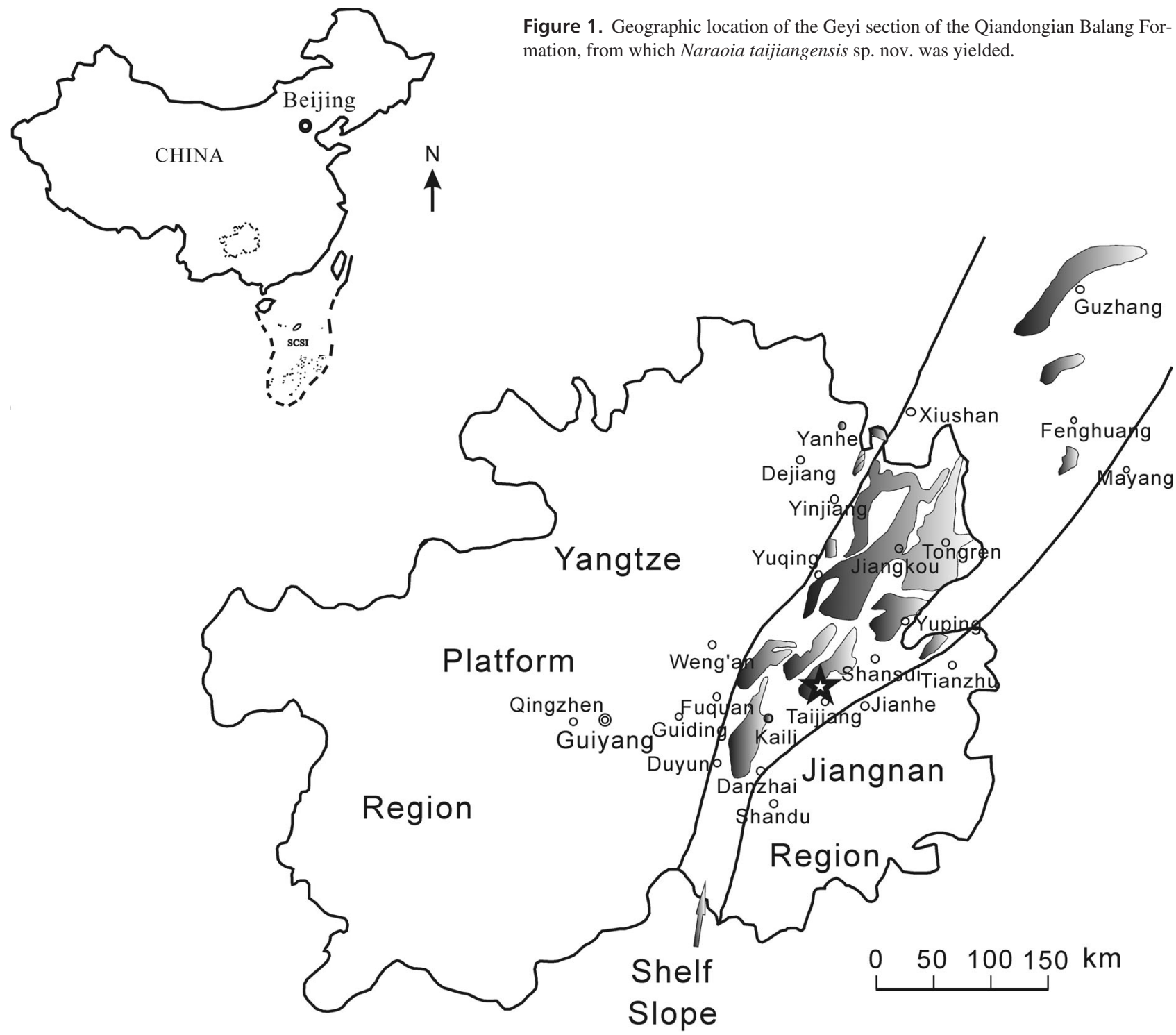

Formation, southern Ontario, Canada. Based on detailed examination for naraoiid material of Burgess and Chenjiang biotas, $N$. halia was been valid again by Zhang et al. (2007). As the result, N. compacta, N. spinifer, N. spinosa, $N$. halia, N. bertiensis were recognized as valid (see Caron et al. 2004, Zhang et al. 2007); N. longicaudata was referred to Misszhouia longicaudata (Chen et al. 1997), and $N$. pammon was recognized as a synonym of $N$. compacta (Whittington 1977, Robison 1984). Here we report a new species of Naraoia from the early Cambrian Balang Formation, Geyi Town, Taijiang County, Guizhou Province, China. The middle-upper part of the Balang Formation in Eastern Guizhou contains a diverse fossil assemblage known as the Balang Fauna (Peng et al. 2005). The Balang Fauna includes representatives of seven major groups, including porifer-chanceleoriids, cnidaries, priapulids, brachiopods, echinodermates, molluscs and arthropods, as well as many trace fossils (Peng 2009). Eocrinoids and trilobites are the most common taxa, and are characteristic members of the Balang Fauna. The very fossiliferous Geyi section of the Balang Formation in Geyi Town, Taijiang County contains the best examples of the Balang Fauna. The new species of Naraoia occurs in upper-middle part of Balang Formation of Geyi Town, Taijiang County, in association with other important components of Balang Fauna, Guizhoueocrinus yui Zhao et al., 2007, the priapulid-worm Hadomopanella, corynexochid trilobites, as well as other fossils (Figs 1, 2). The discovery of the non-mineralized taxon of new species of Naraoia in the Balang Fauna indicates that the Balang Fauna also is a diverse Burgess Shale-type biota from Qiandongian (Cambrian Series 2) of China. The Balang Fauna is intermediate in age between the Chengjiang and Kaili biotas. Many taxa found in the Chengjiang Biota and Balang 
Figure 2. Fossil distribution in the Geyi section of the Qiandongian Balang Formation.

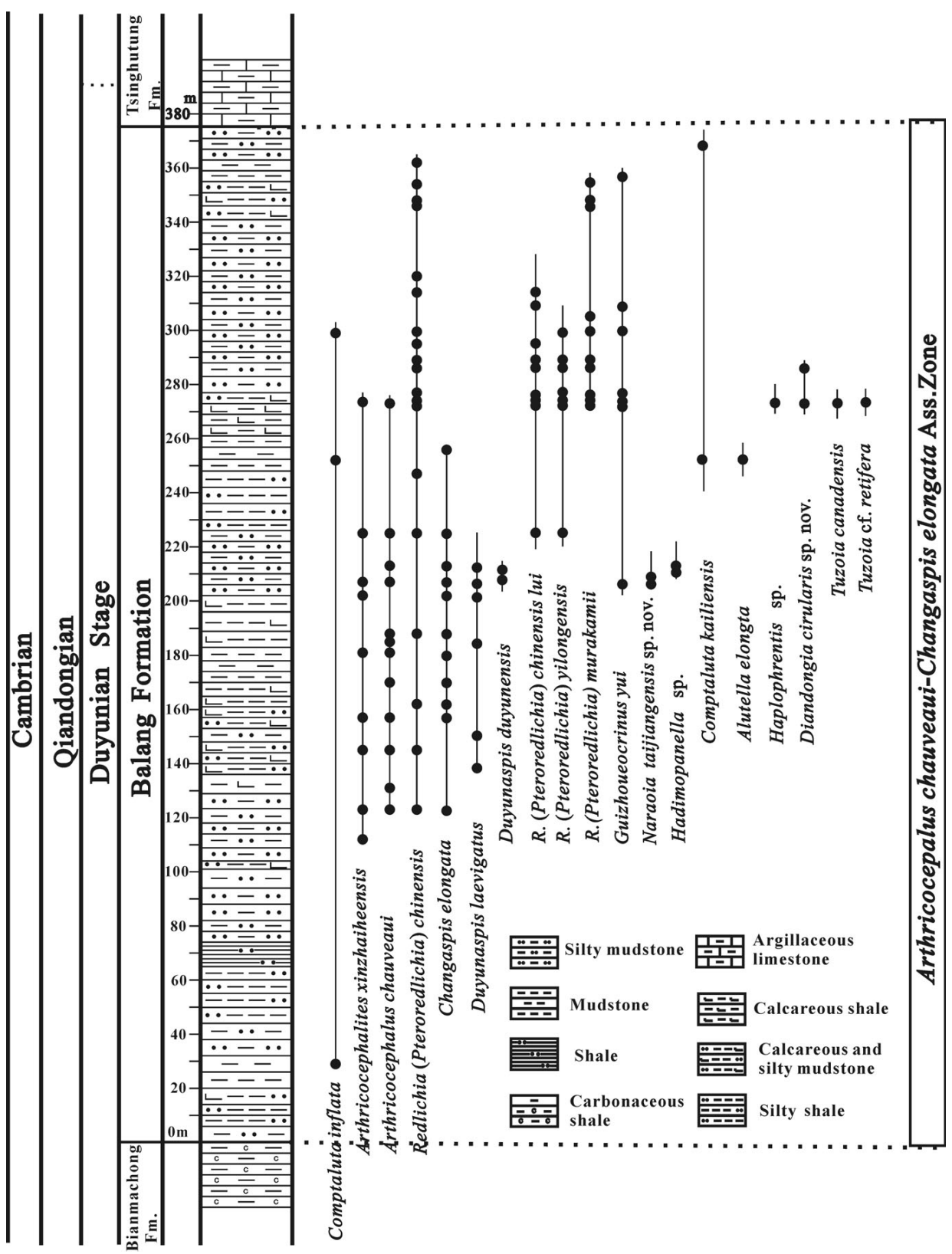

Hunan Province (Zhou et al. 1979; Yin 1987, 1996; see Fig. 1). The lower part of the Balang Formation is composed of gray-greenish to yellow-greenish clayey shale, while the upper part is composed of light gray calcareous shale and silty shale with intercalations of thin-bedded argillaceous carbobates. In general, the Balang Formation from its bottom to its top represents a shallowing-upwards sequence. The formation ranges widely in thickness from $100 \mathrm{~m}$ to more than $658 \mathrm{~m}$ (Yin 1987). Commonly, the Balang Formation is more than $600 \mathrm{~m}$ thick in central eastern Guizhou and commonly more than $300 \mathrm{~m}$ thick in northern Guizhou.

Zhou et al. (1980) and Yin (1987, 1996) proposed the biostratigraphic framework for the Balang Formation
The Balang Formation is mainly limited to a Cambrian outcrop belt in eastern Guizhou Province and western 


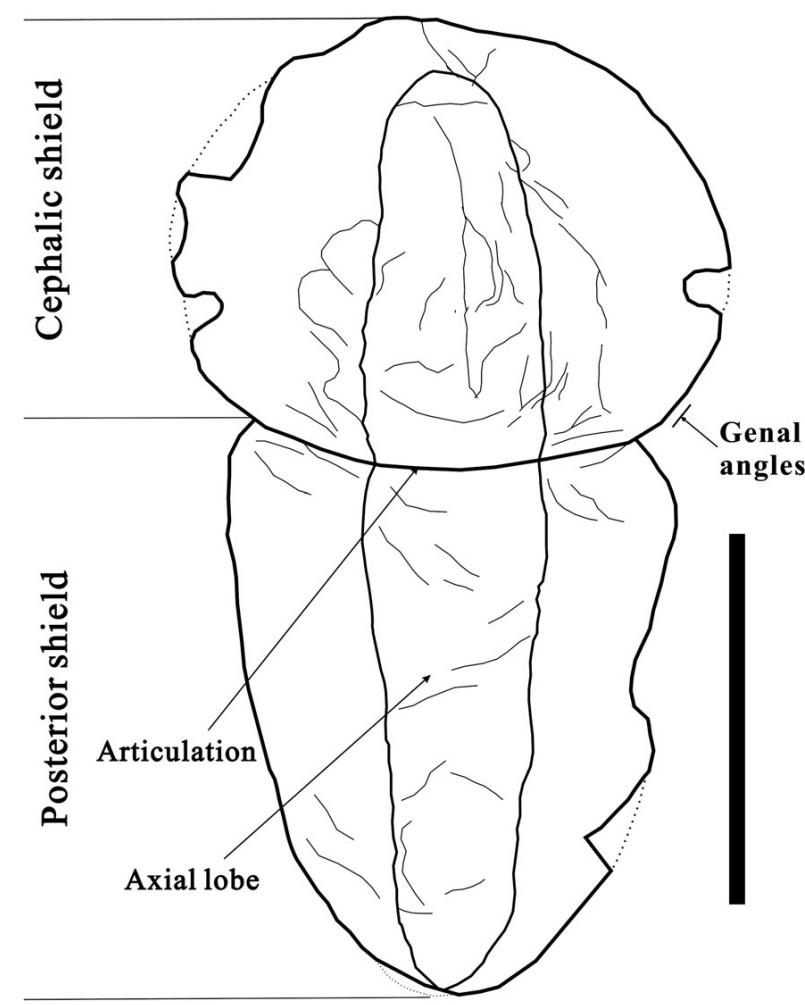

Figure 3. Drawing showing morphological terminology for Naraoia taijiangensis sp. nov., No. GY-172-56, scale bar $=5 \mathrm{~mm}$.

based on trilobites, and considered the entire unit to correspond to the Arthricocephalites-Changaspis-Balangia Assemblage Zone or the Arthricocephalus-Changaspis Assemblage Zone. Based on heterochronic evolution of species of Arthricocephalus Bergeron, 1889, Yuan et al. (2001, 2006) revised this biostratigraphic subdivision and distinguished two separate zones, with the Arthricocephalus jiangkouensis-A. granulus Assemblage Zone in lower part of the Balang Formation and with the Arthricocephalus chauveaui Zone in the upper level of the formation. According to recent revision of biostratigraphy of the Balang Formation in eastern Guizhou, the Arthricocephalus chauveaui-Changaspis micropyge Assemblage Zone was separated by Peng (2009). Recently, the taxonomy of Changaspis micropyge has been discussed by Qin et al. (2010) and Changaspis micropyge was recognized as a synonym of Changaspis elongata. The Balang Formation belongs to the Arthricocephalus chauveaui-Changaspis elongata Assemblage Zone (Qin et al. 2010). Characteristically, the middle-upper parts of this Zone contain abundant Redlichia (Pteroredlichia) chinensis. Arthricocephalus chauveaui, Changaspis elongata are known in the lower Cambrian Henson Gletscher Formation of Greenland; the latter was deseribed as Lancastria plana by Blaker \& Peel (1997, pp. 118-122, figs 69/2, 3, 70, 71/4, 5). In addition, Arthricocephlites taijiangensis, which is common in the
Balang Formation, was assigned to Hailiplaktos jishouensis by Blaker \& Peel (1997, figs 64/5-7). However, according to the correlation using three genera of corynexochid trilobites, the Balang and Henson Gletscher formations are equivalent in age. The Balang Formation is early Cambrian to late Tsanglangpuan in age, equivalent to the early Duyunian of the Cambrian stratigraphic system in slope facies (Peng \& Babcock 2001). According to the criteria for correlation in South China, the Balang Formation is equivalent the $\mathrm{Wu}$ longqing Formation of Yunnan Province in age (Luo et al. 2008, Peng et al. 2010b). The upper part of the Balang Formation contains abundant Redlichia (Pteroredlichia) chinensis Walcott, 1905, and is correlated with the lower part of the Ordian of the Cambrian of Australia (Öpik 1970), that is, the position of the Balang Fauna correlates with those of the Guanshan Fauna and Emu Bay Shale Fauna (Nedin 1995, Luo et al. 2008, Hu et al. 2008, Peng et al. 2010a, b).

The Balang Fauna occurs in the upper part of the Balang Formation near Kaili City, Guizhou Province (Peng et al. 2006, 2007, 2010a, b), however, recent field work show presence of fauna in the middle to upper part of the formation at Jianggu town (Zhengyuan County), at Geyi town (Taijiang County), and at Jiaoban village (Jianhe County, eastern Guizhou Province). The Balang Formation is $375.4 \mathrm{~m}$ thick at the exposure near Geyi Town, Taijiang County, Guizhou Province, where the Balang Fauna assemblage occurs in the middle and upper parts of the formation. Up to now, Naraoia have been described only from the Geyi section, being associated with other components of Balang Fauna, e.g. Guizhoueocrinus yui Zhao et al., 2007, the palaeoscoleid Hodmopanella sp., the trilobites Arthricocephalus chauveaui and Changaspis elongata etc. (Fig. 2).

All described specimens are deposited in the Palaeontological Museum of Guizhou University, Guiyang, China (GU). All specimens in the collection come from the Balang Formation, Geyi Town of Taijiang County, the prefix GY assigned to specimens indicates the Geyi section.

\section{Systematic palaeontology}

Remarks. - Terminology used herein is explained in Fig. 2.

Phylum Arthropoda Siebold \& Stannius, 1845

Class uncertain

Order Nectaspidida Raymond, 1920

Family Naraoiidae Walcott, 1912

\section{Genus Naraoia Walcott, 1912}

Type species. - Naraoia compacta Walcott, 1912. 

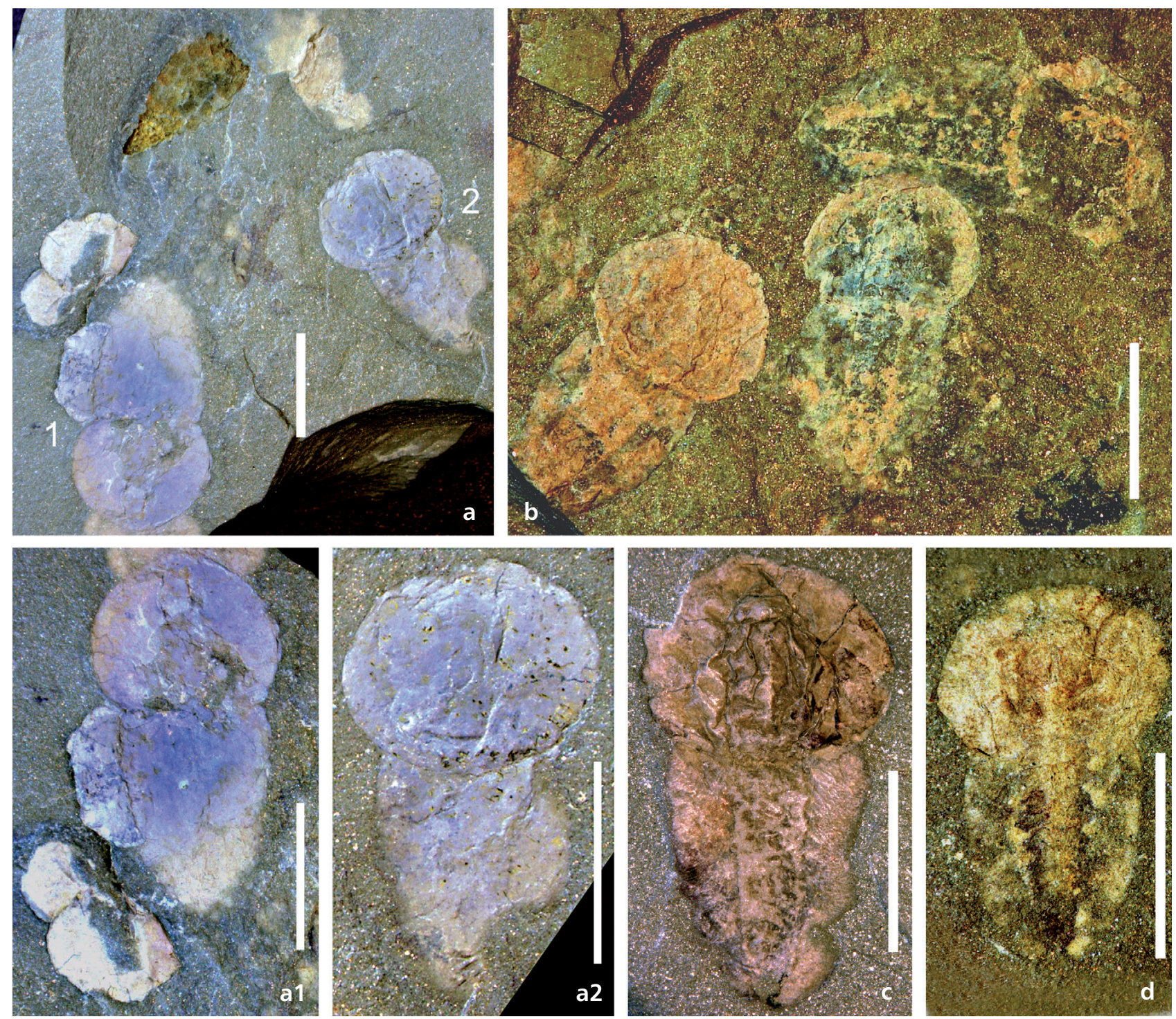

Figure 4. Naraoia taijiangensis sp. nov. from the Geyi section of Qiandongian (lower Cambrian) Balang Formation, Geyi town, Taijiang County, Guizhou Province, South China. • a - three-four dorsal exoskeletons preserved in association with Guizhoueocrinus yui Zhao et al., 2007, No. GY-172-14. • a1 - enlargement 1 of fig. a. $\bullet a 2$ - enlargement 2 of fig. A. $\bullet$ b - three complete dorsal exoskeletons, axial lobes can been seen clearly, paratype, No. GY-172-58. $\bullet$ a complete dorsal exoskeleton, axial lobe can been seen clearly, holotype, No. GY-172-56a. • d - a dorsal exoskeleton, juvenile specimen, abdomenal view, the coax (basis) of 8 paired bilateral axis appendages in posterior shield can been seen clearly, No. GY-178-57a. Scale bars $=5$ mm.

Diagnosis. - A dorsal exoskeleton divided by a single transverse articulation into two shields, a cephalic shield and a posterior shield. The cephalic shield is round to half-round in dorsal view, devolving spinose or nonspinose in genal angles, both lateral margins and rear margin of posterior shield; one pair of lateral project antennas in anterior cephalic area. Axial lobe weak, both lateral axial lobe with alimentary system, including alimentary diverticulae and alimentary canal, with appendages in abdominal region.

Occurrence and horizon. - Canada and America, South China; early Cambrian to upper Silurian.

\section{Naraoia taijiangensis sp. nov.}

Figures 3, 4a1-d

Holotype. - A dorsal exoskeleton preserved in slab of shale (GY-172-56a, Figs 3, 4b, c); cephalic shield $5.84 \mathrm{~mm}$ in length, and $7.07 \mathrm{~mm}$ in width. The cephalic axial lobe $4.45 \mathrm{~mm}$ in length, $c a 2.3 \mathrm{~mm}$ in width. Posterior shield $7.30 \mathrm{~mm}$ in length, and $5.67 \mathrm{~mm}$ in width. The axial lobe $6.76 \mathrm{~mm}$ in length, $c a 2.3 \mathrm{~mm}$ in width.

Paratype material. - Three dorsal exoskeletons preserved in slabs of shale (GY-172-58, Fig. 3, 4b), axial region can be seen clearly. 

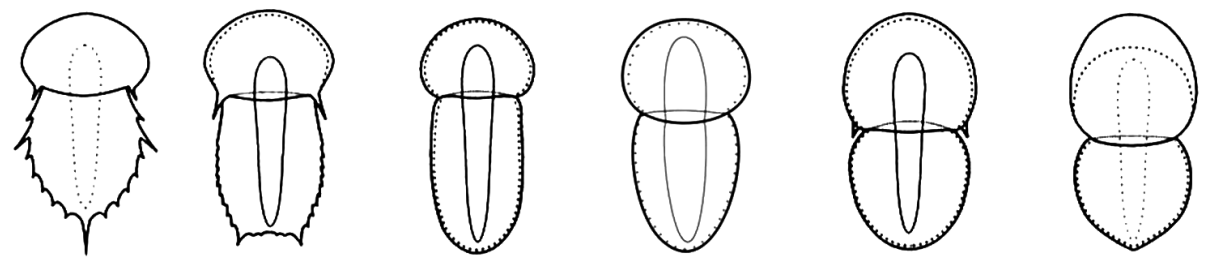

\section{$N$. spinifer $N$. spinosa Misszhouia N. taijiangensis N. compacta N. bertiensis longicaudata sp. nov.}

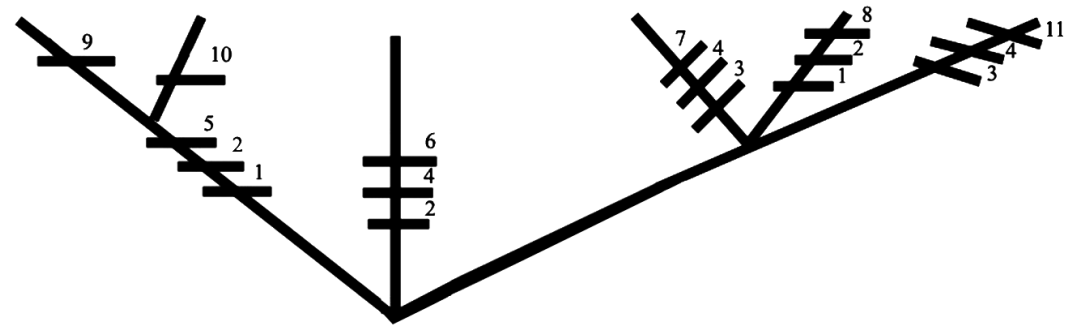

Figure 5. Phylogenetic position of every species between Naraoia and Misszhouia. Numbers refer to derived characteristics as follows: 1 - genal spines; 2 - subcircular cephalic shield, 3 - circular cephalic shield, 4 - round genal angle, 5 - with marginal spines of the posterior shield; 6 - elongate posterior shield, 7 - long elliptic posterior shield, 8 - wide elliptic posterior shield, 9 - single spine of the posterior shield rear margin; 10 - one pair spines of posterior shield rear margin; 11 - wide doublure (based on Caron et al. 2004, fig. 5, modified).
Material. -8 specimens preserved in slabs of shale, and 3 additional counterpart molds.

Etymology. - The species is named for its occurrence in Taijiang County.

Diagnosis. - A species of Naraoia characterized by a nearly circular cephalic shield, round genal angle, and a posterior shield nearly long oval and the maximum width lie on anterior part; without spines in lateral and rear margins of cephalic and posterior shields; axial lobe crassitude in cephalic shield and the posterior shield, and quickly pointed near the rear margin (see Fig. 5).

Description. - Specimens from the Geyi section of the Balang Formation all show the same pertinent features, characterized by a nearly circular cephalic shield, round genal angles, lateral project antennal (Fig. 4d), and a posterior shield that is nearly long oval in outline, the width of posterior shield slightly narrower than that of cephalic shield, the maximum width lie on anterior part and generally tapers backward, showing a long elliptic posterior margin and no marginal spines; axial lobe crassitude in cephalic and the posterior shields. Articulated cephalic and posterior shields are preserved in dorsal aspect and are slightly convex, with patencial overlay area. The axial lobe in the cephalic shield is slightly convex, short, and club-shaped, and slightly wider in median part of the shield, tapering forward, with wrinkles on the surface. The axial lobe in the posterior shield is an elongate column with a smooth surface, and quickly pointed near the rear margin. According to one juvenile specimen (Fig. 4d) there are coax (basis) of 8 paired bilateral axis appendages in posterior shield abdomenal region. Length/width ratio of the posterior shield ranges from 1.28 to 1.3 . No traces of appendages or soft internal anatomy are preserved.
Comparison. - The new species is similar to N. cf. N. compacta from the middle Cambrian Kaili Biota (Zhao et al. 2005, p. 755, pl. III, fig. 13) and N. compacta from Burgess Biota (Walcott 1912, pp. 175-177, pl. 28, figs 3, 4; Whittington 1977, figs 5-8, 79), however, the posterior shields of both latter species exhibit a maximum width located in the medial part of the shield, forward anterior and posterior slightly curved into a wide ellipse, in additional, N. compacta with genal spines in cephalic shield, even those without genal spines (Zhang et al. 2007, pp. 6, 7, fig. 3/1; fig. 4/1, 3-5) showing length/width ratio of the posterior shield $c a 1.0$, differ separately from new species. In addition, the new species exhibits characteristics for round genal angles, a long elliptic posterior margin of the posterior shield and no marginal spines are completely different from $N$. spinifer, $N$. spinosa (morph A and B) (see Zhang et al. 2007, p. 19), and N. halia (see Fig. 5).

\section{Discussion}

The new species also resembles Misszhouia longicaudata from the Chengjiang Biota, Yunnan, China in exoskeleton (Zhang \& Hou 1985, p. 592, pl. I, figs 1, 2; pl. II, figs 2-4; pl. III, figs 1-4). It is known that Misszhouia longicaudata was separated from Naraoia by Chen et al. (1997) based on its antennule orientation, smaller cephalic caeca and gut, lanceolate distal expod lobe, and partial fusion of the expod and first endopodal podomere, and the close relationship to Naraoia in phylogenies is recognized. Easily compared with Naraioa, the characters of Misszhouia are elongated posterior shield and caeca restricted to axial region (see Zhang et al. 2007, p. 31). Although no traces of soft internal anatomical characters of circular cephalic shield were found, lateral project antennal (Fig. 4d), the axial lobe crassitude, and fewer appendages in posterior shield of new species are more similar to that of Naraoia. 
Even juvenile specimens of $M$. longicaudata (see Zhang $e t$ al. 2007, fig. 36/2, 3) showing 16-18 pairs of appendages beneath posterior shield, and length/width ratio of the posterior shield ranges 1.65 to 2.1 (Zhang et al. 2007, fig. 16), completely differ from that of new species. New species should be attributed to Naraoia. According to Zhang et al. (2007) detailed study, 2 species of Naraoia, N. spinosa and $N$. compacta, are more complicated in morphology, which $N$. spinosa with genal and margin spines shows morph A and lack marginal spines of posterior shield shows morph B (Zhang et al. 2007). The latter is some similar to the new species, but possesses characteristics of the genal spines and wide elliptic posterior shield obviously distinguishing from the new species. $N$. compacta without genal spines, original described $N$. pammon also has wide elliptic posterior shield and length/width ratio $c a 1$ obviously distinguishing from new species (see Fig. 4). $N$. cf. compacta from the middle Cambrian Kaili Biota (Zhao et al. 2005; Lin 2006, figs 2,3) most characters are similar to the type species of Naraoia, $N$. compacta. Naraoia has been as an unusual trilobite lacking thoracic segment (Walcott 1912, Raymond 1920, Whittington 1977, Conway Morris 1979, Robison 1984, Zhang \& Hou 1985).

$M$. longicaudata and $N$. spinosa from the Chengjiang Biota lie in Eoredlichia Zone (Cambrian Series 2) (Zhang et al. 2007), N. cf. N. compacta from the Kaili Biota lie in Oryctocephlus indicus Zone (Cambrian Series 3), and new species lies in Arthricocephalus chauveaui-Changaspis elongata Assemblage Zone (Cambrian Series 2, some later than Eoredlichia Zone). The new species clearly represents an intermediate morphology between Misszhouia longicaudata and $N$. cf. $N$. compacta. It is obvious that there is a body-morphologic evolution for Naraoia from the Cambrian Series 2 to Cambrian Series 3 (lower to middle Cambrian). New taxonomic information of Naraoia provides new data about evolution and geographical range of this genus.

Occurrence and horizon. - Geyi town, Taijiang County, Guizhou Province, South China; the Qiandongian (lower Cambrian) Balang Formation.

\section{Acknowledgements}

We thank Feng Hongzhen (Nanjing University) for providing a good suggestion of manuscript. A special acknowledgement is given to R. Gaines (Pomona College, USA) for English corrections in manuscript. We are grateful to two reviewers J. Haug (Yale University, New Haven, USA) and Jihpai Lin (Nanjing Institute of Geology and Paleotology, CAS, PRC) for their comments and valuable suggestions, and two editors M.E. Steiner (Freie University Berlin, Germany) and O. Fatka (Charles University, Czech Republic) for their detailed work. This research was supported in parts by grants from the National Natural Sci- ences Foundation of China (40762001, 41172005), and in parts of the foundations from the Mobile project of Science and Technology of Guizhou Province (Grant No. Gui Ji. 2007-4004), the Key Project of International Cooperation of Guizhou Science and Technology Department (Gui. Co. No. 2008-700110), the State Key Laboratory of Palaeobiology and Stratigraphy (Nanjing Institute of Geology and Palaeontology, CAS; No. 083107; 113111), Paleontological Museum of Shenzhen Xianhu Botanical Garden, and Attracted Talent of Guizhou University (No. 2010021), and the Major Basic Research Projects of MST of China (2006CB806401).

\section{References}

Blaker, M.R. \& Peel, J.S. 1997. Lower Cambrian trilobites from North Greenland. Meddelelser om Grønland Geosciences 35, $1-145$.

Briggs, D.E G., Erwin, D.H. \& Collier, F.J. 1994. The fossils of the Burgess Shale. 236 pp. Smithsonian Institution Press, Washington.

Caron, J.B., Rudkin, D.M. \& Millken, S. 2004. A new late Silurian (Pridolian) naraoiid (Euarthropoda: Nektaspida) from the Bertie formation of southern Ontario, Canada - delayed fallout from the Cambrian explosion. Journal of Paleontology 78(6), 1136-1145.

Conway Morris, S. 1979. The Burgess Shale (Middle Cambrian) fauna. Annual Reviews of Ecology and Systematics 10, 327-349. DOI 10.1146/annurev.es.10.110179.001551

Chen, J.Y., Edgecombe, G.D. \& RAMsKöLd, L. 1997. Morphological and ecological disparity in naraoiids (Arthropoda) from the early Cambrian Chengjiang fauna, China. Records of Australia Museum 49, 1-24.

DOI 10.3853/j.0067-1975.49.1997.249

Hou, X.G., Bergström, J., Wang, H.F., Feng, X.H. \& Chen, A.L. 1999. The Chengjiang Fauna: Exceptionally well-preserved animals from 530 million years ago. $170 \mathrm{pp}$. Yunnan Science and Technology Press, Kunming. [in Chinese with English summary]

Hu, S.X., Li, Y., LuO, H.L., Fu, X.P., You, T., PAng, J.Y., Liu, Q. \& STEINER, M. 2008. New record of palaeoscolecids from the Early Cambrian of Yunnan, China. Acta Geologica Sinica 82(2), 244-248. DOI 10.1111/j.1755-6724.2008.tb00574.x

LiN, J.P. 2006. Taphonomy of Naraoiids (Arthropoda) from the Middle Cambrian Kaili Biota, Guizhou Province, South China. Palaios 21, 15-25. DOI 10.2110/palo.2004.p04-83

Luo, H.L., Li, Y., Hu, S.X., Fu, X.P., Hou, S.G., Liu, X.Y., Chen, L.Z., Li, F.J., Pang, J.Y. \& Liu, Q. 2008. Early Cambrian Malong Fauna and Guanshan Fauna from Eastern Yunnan, China. 134 pp. Yunnan Science and Technology Press, Kunming. [in Chinese with English summary]

Nedin, C. 1995. The Emu Bay Shale, a Lower Cambrian fossil Lagerstätten, Kangaroo Island, South Australia. Australasian Association of Palaeontologists Memoir 18, 31-40.

NEDIN, C. 1999. Anomalocaris predation on nonmineralized and mineralized trilobites. Geology 27, 987-990.

DOI 10.1130/0091-7613(1999)027<0987:APONAM>2.3.CO;2

ÖPIK, A.A. 1970. Redlichia of the Ordian (Cambrian of northern 
Australia and New South Wales). Bulletin of Bureau of Mineral Resources, Geology and Geophysics 114, 1-66.

Patterson, J.H., Edgecombe, G.D., García-Bellido, D.C., JaGo, J.B. \& Gehling, J.G. 2010. Nektaspid arthropods from the Lower Cambrian Emu Bay Shale Lagerstätte, south Australia, with a reassessment of lamellipedian relationships. Palaeontology 53(2), 377-402.

DOI 10.1111/j.1475-4983.2010.00932.x

Peng, J. 2009. The Qiandongian (Cambrian) Balang Fauna from Eastern Guizhou, South China. 137 pp. Master thesis, Nanjing University.

Peng, S.C. \& Babcock, E.L. 2001. Cambrian of the HunanGuizhou region, South China, 3-51. In PENG, S.C., BABCOCK, E.L. \& Zhu, M. (eds) Cambrian System of South China. Palaeoworld 13.

Peng, J., Feng, H.Z., ZhaO, Y.L., Fu, X.P. \& Wang, Y.X. 2007. Tuzoia from the Lower Cambrian Balang Formation, eastern Guizhou, China. Geological Review 53(3), 397-403.

Peng, J., Feng, H.Z., Zhao, Y.L., Fu, X.P. \& Yao, L. 2010b. New bradoriid arthropods from the Early Cambrian Balang Formation of eastern Guizhou, South China. Acta Geologica Sinica 84(1), 56-68. DOI 10.1111/j.1755-6724.2010.00170.x

Peng, J., Zhao, Y.L., Qin, Q., Yan, X. \& MA, H.T. 2010a. New data on brachiopods from the Qiandongian (Lower Cambrian) Balang Formation, eastern Guizhou, South China. Acta Palaeontologica Sinica 49(3), 365-379. [in Chinese with English summary]

Peng, J., Zhao, Y.L., Wu, Y., Yuan, J. \& Tai, T. 2005. The Balang Fauna - a new early Cambrian Fauna from Kaili City, Guizhou Province. Chinese Science Bulletin 50(11), 1159-1162. DOI 10.1360/982005-183

Peng, J., Zhao, Y.L. \& YAng, X.L. 2006. Trilobites of the upper part of Lower Cambrian Balang Formation, southeastern Guizhou Province, China. Acta Palaeontologica Sinica 45(2), 235-242. [in Chinese with English summary]

Qin, Q., Peng, J., Fu, X.P. \& DA, Y. 2010. Restudy of Changaspis (Lee), 1961 from Qiandongian (Early Cambrian) Balang Formation near eastern Guizhou, south China. Acta Palaeontologica Sinica 49(2), 220-230. [in Chinese with English summary]

RAYMOND, P.E. 1920. The appendage, anatomy, and relationships of trilobites. Memoirs of the Connecticut Academy of Arts and Sciences 7, 1-169.

Robison, R.A. 1984. New occurrences of the unusual trilobite Naraoia from the Cambrian of Idaho and Utah. The University of Kansas Paleontological Contributions 112, 1-8.

Simonetta, A.M. \& Delle Cave, L. 1975. The Cambrian non-trilobite arthropods from the Burgess Shale of British Columbia. A study of their comparative morphology, taxonomy and evolutionary significance. Palaeontographica Italica 69, 1-37.

Steiner, M., Zhu, M.Y., Zhao, Y.L. \& Erdtmann, B.-D. 2005. Lower Cambrian Burgess Shale-type fossil associations of South China. Palaeogeography, Palaeoclimatology, Palaeoecology 220, 129-152. DOI 10.1016/j.palaeo.2003.06.001

WalcotT, C.D. 1912. Middle Cambrian Branchiopoda, Malacostraca, Trilobita and Merostomata. Cambrian geology and paleontology II. Smithsonian Miscellaneous Collections 57, $145-228$.
Walcott, C.D. 1931. Addenda to description of Burgess Shale fossils. Smithsonian Miscellaneous Collections 85, 1-46.

Whittington, H.B. 1977. The Middle Cambrian trilobite Naraoia, Burgess Shale, British Columbia. Philosophical Transactions of the Royal Society of London, Series B 280(974), 409-443. DOI 10.1098/rstb.1977.0117

Yin, G.Z. 1987. Cambrian, 49-96. In BuREau of Guizhou Geology And Mineral Resources (ed.) Regional Geology of Guizhou Province. Geological Memories series 1(7). PRC Ministry of Geology and Mineral Resources, Geological Publishing Press, Beijing. [in Chinese with English summary]

YIN, G.Z. 1996. Division and correlation of Cambrian in Guizhou. Guizhou Geology 13(2), 115-128. [in Chinese with English abstract]

YuAn, J.L., ZhaO, Y.L. \& Li, Y. 2001. Biostratigraphy of oryctocephalid trilobites. Acta Palaeontologica Sinica 40 (Supplement), 143-156.

YuAN, J.L., ZHAO, Y.L. \& YANG, X. 2006. Speciation of the genus Arthricocephalus Bergeron, 1899 (Trilobita) from the late Early Cambrian and its stratigraphic significance. Progress in Natural Science 16(6), 614-623.

DOI 10.1080/10020070612330043

Zhang, W.T. \& Hou, X.G. 1985. Preliminary notes on the occurrence of the unusual trilobite Naraoia in Asia. Acta Palaeontologica Sinica 24, 591-595. [in Chinese with English abstract]

Zhang, X.L., Shu, D.G. \& ERwin, D.H. 2007. Cambrian naraoiids (Arthropoda), morphology, ontogeny, systematics, and evolutionary relationships. Journal of Paleontology 81, 1-52. DOI 10.1666/06-082.1

Zhou, Z.Y., Yuan, J.L., Zhang, Z.H., Wu, X.R. \& Yin, G.Z. 1979. The Cambrian bio-geographical realm divided in Guizhou Province, South China and adjacent to region. Journal of Stratigraphy 3(4), 258-271. [in Chinese]

Zhou, Z.Y., Yuan, J.L., Zhang, Z.H., Wu, X.R. \& Yin, G.Z. 1980. System and correlation of Cambrian stratigraphies in Guizhou, China. Journal of Stratigraphy 4(4), 273-281. [in Chinese]

Zhao, Y.L., Parsley, R.L. \& Peng, J. 2007. Early Cambrian eocrinoids from Guizhou Province, South China. Palaeogeography, Palaeoclimatology, Palaeoecology 254, 317-327. DOI 10.1016/j.palaeo.2007.03.020

Zhao, Y.L., Yuan, J.L., Zhu, M.Y., Yang, R.D., Guo, Q.J., PENG, J. \& YANG, X.L. 2002. Progress and significance in research on the early Middle Cambrian Kaili Biota, Guizhou Province, China. Progress in Natural Science 12(9), 649-654.

ZhaO, Y.L., Yuan, J.L., Zhu, M.Y., Yang, R.D., GuO, Q.J., QIan, Y., HuAnG, Y.Z. \& PAN, Y. 1999. A progress report on research on the early Middle Cambrian Kaili Biota, Guizhou, PRC. Acta Palaeontologica Sinica 38 (Supplement), 1-14. [in Chinese with English abstract]

ZhaO, Y.L., Zhu, M.Y., Babcock, L.E., Yuan, J.L., Parsley, R.L., Peng, J., YAng, X.L. \& Wang, Y. 2005. Kaili Biota: A taphonomic window on diversification of metazoans from the basal Middle Cambrian, Guizhou, China. Acta Geologica Sinica 79(6), 751-765.

DOI 10.1111/j.1755-6724.2005.tb00928.x 